\title{
MENATA ULANG KONSEP DAN PRAKTIK PENDIDIKAN ISLAM
}

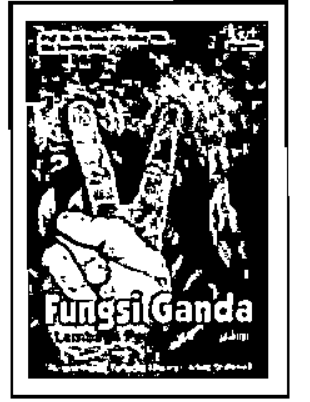

Judul

Penulis

Cet/Tahun

Penerbit

Halaman
: Fungsi Ganda Lembaga Pendidikan Islam

(Respon Kreatif terhadap Undang-Undang

Sisdiknas)

: Usman Abu Bakar dan Surohim

: I/ Januari 2005

: Safiria Insania Press Yogyakarta

: xii + 188 halaman.

Ada semacam stereotyping di masyarakat kita, bahwa pendidikan Islam selalu diasosiasikan dengan lembaga pendidikan terbelakang. Hal ini tidak dapat dipungkiri karena pendidikan Islam terutama pendidikan tingginya, sering tidak menghasilkan lulusan (educational output) yang memadai, tidak memiliki kemampuan komprehensifkompetitif terutama dalam bidang ilmu pengetahuan (science) dan tidak memiliki kompetensi profesional seperti yang dituntut dunia kerja (work force). Kondisi obyektif demikian ini menempatkan lembaga pendidikan Islam bukan sebagai kelas utama (the first class) melainkan sebagai kelas kedua (the second class). Hal ini dapat dilihat secara nyata dengan tingginya kecenderungan lulusan pendidikan Islam yang memasuki perguruan tinggi agama Islam sementara sangat sedikit jumlah lulusan pendidikan Islam yang memasuki perguruan tinggi umum, dan itupun hanya terbatas pada bidang-bidang ilmu humaniora saja.

Disahkannya Undang-Undang No. 20 tahun 2003 tentang Sistem Pendidikan Nasional memberi insiatif tersendiri bagi-pengembangan mutu lembaga-lembaga pendidikan Islam. Undang-Undang Sistem Pendikan Nasional (UU Sisdiknas) yang secara garis besar menggariskan tentang Dasar, Fungsi dan Tujuan Pendidikan; Prinsip Penyelenggaraan Pendidikan; Hak dan Kewajiban; Standar Nasional Pendidikan; Kurikulum; Pendidik dan Tenaga Kependidikan; Sarana dan Prasarana Pendidikan; Pendanaan Pendidikan; dan Pengelolaan Pendidikan, telah memberi peluang yang besar bagi lembaga-lembaga pendidikan Islam untuk menunjukkan eksistensinya di tengah-tengah persaingan lembaga pendidikan nasional.

Bertolak dari fenomena inilah, buku Fungsi Ganda Lembaga Pendidikan Islam (Respon Kreatif terbadap Undang-Undang Sisdiknas) yang ditulis Usman Abu Bakar dan Surohim, berupaya mengupas secara tuntas berbagai problematika yang dihadapi lembaga-lembaga pendidikan Islam, serta peran besar UU Sisdiknas dalam memberikan keleluasaan kepada lembaga-lembaga Pendidikan Islam untuk lebih bersikap mandiri, progresif dan inovatif. 
Secara garis besar, ada empat permasalahan yang dihadapi pendidikan Islam di Indonesia, yaitu: Pertama, persoalan penduduk, yang menyangkut kurangnya pemahaman umat untuk saling memahami perbedaan, sebingga masih berpotensi konflik. Kedua, persoalan wawasan, yang menyangkut kecenderungan umat untuk berpikir dikotomis dalam memandang realitas pendidikan Islam. Ketiga, persoalan dana, yang terkait dengan kurangnya dana dalam memenuhi kebutuhan penyelenggaraan satuan pendidikan Islam dalam berbagai hal. Keempat, persoalan membangun pendidikan Islam secara terpadu, yang terkait dengan pencarian sistem pendidikan alternatif sebagai sintesa dari berbagai sistem pendidikan yang pernah ada (pp. 84-88).

Semua persoalan di atas, dalam pandangan penulis buku, bertolak belakang dengan ajaran Islam yang sesungguhnya. Paradigma pendidikan Islam sejatinya berwawasan semesta (rabmatan lil 'alamin), yang mencakup wawasan ketuhanan, wawasan kemanusiaan, dan wawasan tentang alam. Wawasan pertama akan menumbuhkan sikap ideologi, idealisme, cita-cita dan perjuangan. Wawasan kedua akan menumbuhkan kearifan, kebijaksanaan, kebersamaan, demokratis, egalitarian dan menjunjung tinggi hak asasi manusia. Sedangkan wawasan ketiga akan melahirkan semangat dan sikap ilmiah, sehingga melahirkan ilmu pengetahuan dan teknologi, serta kesadaran yang mendalam untuk melestarikannya (p. 122).

Berdasarkan paradigma tersebut, menurut penulis buku ini, dunia pendidikan Islam perlu berbenah dan menyusun strategi pembaharuan (reformulasi) konsep dirinya dengan langkah-langkah: Pertama, membangun kerangka filosofis dan teoritis pendidikan Islam. ${ }^{1}$ Kedua, membangun sistem pendidikan Islam yang diproyeksikan melalui laboratorium fungsi ganda, yang meliputi peningkatan mutu akademik dan pengembangan usaha bisnis. ${ }^{2}$

Secara paradigmatik,-konsep pendidikan yang dikemukakan penulis buku tidak jauh berbeda dengan para pendahulunya, misalnya Syed Naquib al-Attas dan Ismail

'Untuk membangun ketangka filosofis dan teoritis pendidikan, harus dipahami terlebih dahulu bahwa yang menjadi obyek garapan pendidikan adalah manusia itu sendiri. Dalam pandangan Islam, potensi nafs dan ilmu pengetahuan sejatinya diarahkan pada dimensi positif, sehingga kemudian manusia dapat memposisikan dirinya di muka bumi ini sebagai hamba Allah (abdnllab) dan wakil Allah (khalifatullab) sekaligus. Dengan demikian, secara fungsional keberadaannya memiliki dimensi ketuhanan, dimensi kemanusiaan, dan dimensi kealaman, dalam kerangka menjadi pemeran utama terwujudnya tatanan hidup yang rabmatan kl'alamin (p. 133).

${ }^{2}$ Untuk membangun sistem pendidikan Islam, secara garis besar ada dua hal yang perlu diperhatikan, yaitu: Pertama, peningkatan mutu akademik yang mencakup 1) perumusan visi, misi, dan tujuan pendidikan; 2) pengembangan kurikulum dan materi ajar pendidikan dengan prinsip diversifikasi; 3) metodologi petnbelajaran; 4) profesionalitas pendidikan dan tenaga kependidikan; 5) pengembangan manajemen; 6) pengadaan sarana dan pra satana; dan 7 ) membangun jaringan kemitraan (ketzorking). Kedua, pengembangan usaha bisnis (p. 124). 
Raji' al-Faruqi serta beberapa pemikir pendidikan Islam lainnya di tingkat nasional maupun dunia. Semuanya memposisikan umat manusia sebagai hamba Allah sekaligus wakil Allah di bumi yang berorientasi pada pembentukan insan kamil yang bervisi rabmatan lil'alamin, atau dalam bahasa penulis buku, berwawasan semesta. Buku ini juga memiliki semangat integrasi ilmu pengetahuan-Islam. Namun sayangnya, buku ini tidak menjelaskan secara jelas konsep integrasi yang diinginkan. ${ }^{3}$

Hal baru dari buku ini adalah kontekstualisasi pemikiran pendidikan Islam dalam merespon ditetapkannya UU Sisdiknas. UU Sisdiknas yang memiliki semangat otonomi menjadi pijakan lembaga-lembaga pendidikan Islam untuk lebih bersikap dinamis, otonom, dan mandiri. Selain itu, buku ini menawarkan konsep membangun sistem pèndidikan Islam yang diproyeksikan melalui laboratorium fungsi ganda. Ini adalah sebuah gagasan yang perlu diperhatikan secara serius oleh lembaga-lembaga pendidikan di Indonesia

Secara umum, buku ini sangat menarik dan sangat penting untuk dibaca dan dikaji oleh pemerhati, akademisi maupun praktisi pendidikan Islam. Namun demikian menurut pandangan reviewer, penulis buku ini sangat terpaku dengan pendidikan -- Islam dalam pengertian ajaran Islam sebagai bidang studi. Padahal pemaknaan terhadap realitas pendidikan Islam kontemporer tidak sesederhana itu. ${ }^{4}$ Oleh karena itu, buku ini akan semakin menarik jika dilengkapi dengan pembahasan secara jelas tentang pemaknaan dan bentuk'atau model pendidikan Islam yang berkembang di Indonesia.

Dalam studi kependidikan, sebutan "pendidikan Islam" pada umumnya, dipahami sebagai suatu ciri khas, yaitu jenis pendidikan yang berlatar belakang keagamaan. ${ }^{5}$ Batasan yang lebih rinci tentang model pendidikan Islam, dapat

${ }^{3}$ Sebagaimana diketahui, integrasi ilmu pengetahuan-Islam akhir-akhir ini sangat matak dibicarakan oleh para akademisi dan praktisi pendidikan Islam. Salah satu wujud maraknya semangat integrasi tersebut adalah perubahan beberapa IAIN di Indonesia menjadi UIN, misalnya UIN Syarif Hidayatullah Jakarta, UIN Sunan Kalijaga Yogyakarta, dan UIN Malang. Masing-masing UIN tersebut

- memiliki konsep integrasi yang berbeda satu sama lainnya. Buku ini belum menunjukkan identitas - konsep integrasi yang dimaksud, konsep al-Attas atau al-Faruqi (Lihat dan bandingkan Ismail Raji Al Faruqi (1982), Islamization of Knowledge: General Principle and Workplan, Washington: IIIT dan Syed Muhammad Naquitb Al Attas (1978), Islam and Sectlanism, Kuala Lumpur: ABIM.

${ }^{4}$ Pendidikan Islam di Indonesia mengalami dinamisasi pemikiran sejak zaman masuknya Islam ke Indonesia hingga era reformasi saat ini. Dalam perkembangannya, pendidikan Islam menunjukkan model dan bentuk yang terus mengalami perubahan dan peningkatan. Secara historis institusional, ada lima jenis pendidikan Islam yang berkembang sampai saat ini, yaitu-masjid dan surau, pondok pesantren, madrasah, perguruan tinggi agama Islam, majelis ta'lim, sekolah umum dan perguruan tinggi umum yang memiliki karakter atau nilai Islam. Lithat Hasbullah (1999), Sejarab Pendidikan Islam di Indonesia: Lintasan Sejarab Pertumbuban dan Perkembangan, Jakarta: PT RajaGrafindo Persada).

${ }^{5}$ Karel A Steenbrink (1986), Pesantren, Madrasah, dan Sekalab: Pendidikan Islam dalam Kurun Modem, Jakarta: LP3ES, p. 122. 